Revista de Estudios Histórico-Jurídicos

[Sección Derecho Romano]

XXXI (Valparaíso, Chile, 2009)

[pp. 125 - 139]

\title{
FREEDOM OF SPEECH IN ROME
}

\author{
["Libertad de expresión en Roma"]
}

\author{
José Manuel Díaz de Valdés* \\ Universidad del Desarrollo
}

\begin{abstract}
RESUMEN
Este trabajo reflexiona sobre la existencia y el ejercicio de la libertad de expresión en Roma. Luego de postular que los romanos consideraban a la libertad de expresión como parte integrante de las libertades otorgadas por el régimen republicano, se afirma que aquella no era entendida como un derecho humano, sino más bien como una prerrogativa de carácter político. Como en la actualidad, la libertad de expresión era valorada no sólo por su importancia para el emisor, sino también por su relevancia para el sistema político. El artículo señala que este derecho fue intensamente ejercido durante la República, tanto en ámbitos institucionales como no-institucionales. Entre los primeros encontramos a los contiones, el Senado, los tribunales y, sorprendentemente, el ejército. Los segundos correspondían principalmente al Foro, asociaciones privadas y algunas manifestaciones artísticas. La llegada del Imperio afectó profundamente a la libertad de expresión. Aunque no desapareció completamente, dejó de ser
\end{abstract}

\section{Abstract}

This paper reflects on the existence and exercise of freedom of speech in Rome. After asserting that Romans considered free speech as part of the liberties provided by the Republican regime, it is affirmed that it was not regarded as a human right but as a political entitlement. As nowadays, freedom of speech was valued not only for its importance to the speaker, but also for its relevance to the political system. The paper states that during the Republic, this right was intensively exercised trough both institutional and not institutional settings. Among the former were the contiones, the Senate, the courts and, surprisingly, the army. The latter were mainly the Forum, private associations and some kind of arts. The advent of the Empire deeply affected freedom of speech. Although it did not disappeared altogether, it ceased to be considered as a right (it was only tolerated) and became troublesome to the new political regime. Regarding its legal status, freedom of speech was never recognized as a right

* Professor of Constitutional Law at Universidad del Desarrollo. Mailing address: Avenida Plaza No 700, Las Condes, Santiago, Chile. E-mail: jdiazdevaldes@udd.cl 
considerada como un derecho (fue sólo tolerada), y devino en problemática para el nuevo régimen político. En cuanto a su estatus jurídico, la libertad de expresión nunca fue reconocida legislativamente como un derecho. En contraste, las restricciones legislativas a la libertad de expresión evolucionaron desde un suave comienzo bajo las XII Tablas, hacia una creciente severidad al final de la República, alcanzando gran dureza durante el Imperio.

Palabras clave: Libertad de expresión -- Lex Maiestatis - Injuria/Calumnia. by statute. In contrast, legal restrictions evolved from a soft start under the XII Tables, to increasing severity at the end of the Republic, to straight harshness during the Empire.

KEYWORDS: Freedom of Speech - Lex Maiestatis - Libel.

\section{INTRODUCTION ${ }^{1}$}

Nowadays nobody doubts that freedom of speech is one of the building blocks of Western political regimes. However, was it so in Rome? Did Romans enjoy a meaningful freedom of speech?

To answer these questions it is important to bear in mind that the application of contemporary conceptual constructions to Rome is hardly appropriate, and therefore a functional approach should be adopted. In other words, emphasis should be given to the practical exercise of freedom of speech in the Roman world as well as to the role it played in the political system.

In this context, the main thesis of this paper is that beyond a vague (but sufficient) theoretical framework ${ }^{2}$, there was a strong and varied practice of freedom of speech in Rome, at least during the Republic. Secondary thesis will be explored under each of the subsequent headings.

\section{DID ROMANS HAVE ANY CONSCIOUSNESS ABOUT FREEDOM OF SPEECH?}

I would say yes, even though the absence of an unequivocal Roman word or concept for freedom of speech could be taken as a lack of such consciousness ${ }^{3}$. The fact is that Roman life was too full of examples of freedom of speech to doubt

${ }^{1}$ I would like to express my gratitude to my assistants Mr. Nicolás Enteiche Rosales and Mr. Miguel Anabalón Torres for their help and dedication to this research project. I am also in debt with Dr. Gerardo Vidal Guzmán, who was very helpful in the translation of Roman and Greek texts.

${ }^{2}$ This vagueness is not exceptional in Rome. In fact, Earl highlights the "essential vagueness common to all Roman political thought". See: EArL, Donald, The Moral And Political Tradition of Rome (London, 1967), p. 63.

${ }^{3}$ RaAflaub, Kurt A., Aristocracy and Freedom of Speech in the Greco-Roman World in Sluiter, Ineke - Rosen, Ralph M. (eds.), Free Speech in Classical Antiquity (Leiden, 2004), p. 44 . 
it. Romans seemed to have highly enjoyed the right 'to speak one's mind', and used it "in daily life, in comedy, in the courts. Awareness was strong and widespread that this was an important part of the citizens' freedom (...)" it is plausible that constant exercise of freedom of speech breed a conviction in citizens that this was not a mere licencia granted by the state, but something to which they were entitled to, even legally.

The idea of freedom of speech originated as a social notion (contrasting free persons with slaves $)^{5}$, but it was transformed into a political idea thanks to two crucial concepts: libertas and Respublica. Even though the former is very controversial due to its vastness and flexibility, it would at least have entailed an ideal of political freedom against tyranny, which in turn would have comprehended the citizens' freedom of speech ${ }^{6}$. As per Respublica, it clearly "denoted a bare minimum of political rights"

From combining both concepts above, it is plausible to infer that a common Roman citizen understood that because he formed part of a Respublica (and so he was not the subject of a monarchy or tyranny), he enjoyed libertas, that is, a general freedom provided for the political system, which covered his right to speak his mind.

\section{DID ROMANS CONSIDER FREEDOM OF SPEECH AS A 'HUMAN RIGHT'?}

I would say no. Generally speaking, the concept of human rights as entitlements that steam from a commonly shared human dignity was foreign to the Roman world. Firstly, the source of rights (at least of most of them) was not human dignity but citizenship. Romans never developed a conception were "the individual has any absolute value simply by virtue of being a human being" Secondly, and as a consequence of the above, there were large groups deprived of most rights such as women, children, slaves and foreigners9. Thirdly, liberties were only understood in the context of the Respublica. Thus, disregarding the equivocal nature of such a concept, it was clear that the political system, not nature, was the provider of liberties. Finally, the Roman Republic was heavily elitis $\mathrm{t}^{10}$, and therefore the exercise of the rights and liberties conferred by it was primarily for a small minority, not for all human beings.

${ }^{4}$ Raaflaub, Kurt A., cit (n. 3), p. 55.

${ }^{5}$ RaAflaub, Kurt A., cit (n. 3), p. 43.

${ }^{6}$ Chrissanthos actually affirms that libertas "bestowed freedom of speech on Roman citizens". See Chrissanthos, Stefan, Freedom of Speech and the Roman Republican Army, in Sluiter, Ineke and Rosen, Ralph M. (eds.), Free Speech in Classical Antiquity (Leiden, 2004), p. 342.

${ }^{7}$ EARL, Donald, cit. (n. 2), p. 63.

${ }^{8}$ Wiltshire, Susan, Greece, Rome, and the Bill of Rights (Norman, 1992), p. 28.

${ }^{9}$ Wiltshire, Susan, cit. (n. 8), p. 27.

${ }^{10}$ For a general perspective, see: RaAflaub, Kurt A., cit (n. 3). Also see: EarL, Donald, cit. (n. 2); and Millar, Fergus, The Roman Republic in Political Thought (Hanover, 2002), pp. 135-182. 


\section{DID FREEDOM OF SPEECH HAVE INDIVIDUAL VALUE, SOCIAL VALUE, OR BOTH?}

Freedom of speech presents two main distinguishable aspects. On one hand it is valuable as an individual right closely related to the concepts of self-determination, autonomy, liberty and development of the human nature. From this "right-centered" perspective, freedom of speech should be protected because of its crucial importance to the speaker. On the other hand, freedom of speech also has a high social value as a key instrument for the political regime. Thus, political criticism and dissenting opinions are considered essential for the well functioning and advancement of libertarian political systems. From this perspective, freedom of speech is sheltered because of its importance to the listener, which is society as a whole.

In my opinion, both aspects of freedom of speech were present in the Roman world, combined in the concept of citizenship. Thus, the individual right to talk seems to have been much appreciated by Romans, who exercised it in numerous ways, as we will see in section V below. Soldiers in campaigns; senators in the Senate; common citizens in the Forum; historians in their writings; artists in their work, etc., all of them certainly understood free speech as a privilege attached to their quality as citizens (as opposed to mere subjects without political rights).

Additionally, the concept of citizenship was also closely connected with that of Respublica, which was the business all citizens had to take care of ${ }^{11}$. In spite of the elitist character of the Roman system and of the practical difficulties imposed by an ever-extending empire, the importance of political participation (in a broad sense) was quite clear for Romans. Thus, political criticism was widespread; the 'right' to speak could sometimes be considered a duty; and no slander lawsuits from invectives in the Senate and the comitia were accepted ${ }^{12}$. Courts, plays and poems were commonly used to discuss public affairs and to attack political enemies, sometimes in a vicious way ${ }^{13}$. Satire was also an important check over those who had power ${ }^{14}$.

${ }^{11}$ It is plausible to think that this idea was quite extended thanks to the Greek influence. As Thucydides points out, referring to Athenians: "monoi gar ton te mêden tônde metechonta ouk apragmona all' achreion nomizomen". THUCYDIDES, The Peloponnesian War, 2,40,1.: "for, unlike any other nation, regarding him who takes no part in these duties not as unambitious but as useless". Epictetus also highlights the common good over the private profit. See: EрICTETUS, The Discourses (1925, eng. trad., Cambridge), I, p. 275.

${ }^{12}$ Robinson, Laura, Freedom Of Speech in the Roman Republic (Baltimore, 1940), p. 15, attributes it to the fact that: "only by the free expression of opinions could the Republican government function".

${ }^{13}$ Bauman, Richard, Human Rights in Ancient Rome (London, 2000), p. 103, states that: "This various forms of character-assassination display the Roman equivalent of the media at work in the sphere of public life".

${ }^{14}$ It could be argued that personal attacks cannot be equated with political criticism, but that is a distinction difficult to apply in a society were there were no real 'government' in the modern sense, nor political parties, but just individuals who competed for their fellows' support. Thus, personal attacks, when based in truthful information, played an important political function. Morton Braund, Susanna, Libertas or Licentia? in SLuiter, Ineke and 
Summing up, Roman citizens seem to have valued freedom of speech not only as a tool of personal self-fulfillment, but also as a mechanism to influence and control political power. Later on, the empire changed most of the above. As we will see in section $\mathrm{V}$ below, the new political system did not need, and in fact was antagonist to, political criticism. Restrictive laws were enacted, real deliberative power was suppressed, and thus both dimensions of freedom of speech were severely affected.

\section{HOW DID ROMANS EXERCISE THEIR FREEDOM OF SPEECH?}

Two periods should be distinguished in Roman history to answer this question: the Republic and the Empire.

\section{The Republic.}

It is possible to differentiate institutional and non-institutional settings. The main institutional scenarios for freedom of speech in this period were the contio, the Senate, the comitia, the courts and the army. The principal non-institutional venues for it where the Forum, privates associations and some kinds of art.

The extend to which freedom of speech was a feature of the contio (popular meetings without legal powers, convened by magistrates) is disputable. To some their "purpose was information, not open discussion" 15 , and therefore permission to address the audience was subject to tight control ${ }^{16}$. Other authors highlight the facts that tribunes of the plebs could also convene contio ${ }^{17}$, and that commoners sometimes requested and were granted permission to speak to the crowd ${ }^{18}$.

Even adopting the restricted view about the nature and extend of popular participation in the contio, they are still very important from a freedom of speech perspective. In fact, the passing of relevant information about public affairs to citizens is a condition to have a politically meaningful exercise of freedom of speech. Moreover, even if not allowed to held a formal discussion with the 'official speakers', the audience could always cheer, shout, applaud, etc., actions that should also be considered as 'speech'19.

The Senate was much more a deliberative assembly, and thus senators were supposed to exercise a great amount of free speech ${ }^{20}$. In fact, sometimes they

Rosen, Ralph M. (eds.), Free Speech in Classical Antiquity (Leiden, 2004), p. 417, based in Horace, states that: "the comic dramatists deployed truly masculine speech which benefited society by depicting malefactors in an unfettered manner".

${ }^{15}$ Raaflaub, Kurt A., cit (n. 3), p. 54.

${ }^{16}$ Millar, Fergus, cit (n. 10), p. 144. See also Wiltshire, Susan, cit. (n. 8), p. 127.

${ }^{17}$ Brunt, P.A, Laus Imperii in Garnsey, P.D.A - Whittaker, C.R. (eds.), Imperialism in the Ancient World (Cambridge, 1978), p. 55.

${ }^{18}$ Chrissanthos, Stefan, cit. (n. 6), p. 345.

${ }^{19}$ Chrissanthos, Stefan, cit. (n. 6), p. 345.

${ }^{20}$ Robinson, Laura, cit. (n. 12), p. 37. See also Tacitus, Annals, 13, 49: "licere patribus, quoties ius dicendae sententiae accepissent, quae vellent expromere relationemque in ea postulare" ("The Senators, as often as they received the privilege of stating an opinion, were at liberty to say out what they pleased, and to claim that it should be put to vote"). 
went very far indeed, as did Cicero facing Piso, calling him beast, fury, piece of senseless cattle, bit of rotten flesh, hog, filth, disgrace, among other similar expressions $^{21}$. However, slander actions for speech at the Senate are unknown ${ }^{22}$. Moreover, the undeniable aristocratic character of the Senate could have had something to do with the free speech taking place in it $^{23}$. Notwithstanding the above, some authors affirm that freedom of speech was extremely limited in the Senate ${ }^{24}$. In fact, the right of senators to replicate and to intervene more than once in the debate is controversial ${ }^{25}$, as it is the degree of control over the discussion by the leading magistrates ${ }^{26}$, and the effective participation of junior senators in the deliberations.

In my opinion, the extend of free speech in the Senate could very likely have been variable, depending on the political conditions of the time, the character and influence of the magistrates, the nature of the business at hand, etc. However, senators seem to have not had many limits on their privilege to $\operatorname{speak}^{27}$, or on their rights to digress from the central topic, to ask questions, or even to change their sentential28. Additionally, some of the descriptions of senatorial debates give a strong impression of much freedom of speech, including direct or indirect critic against the governing magistrates ${ }^{29}$. Moreover, voting was not secret (only exceptionally during the empire ${ }^{30}$ ) but open to those who were at the Senate, and then to the public at large ${ }^{31}$. In sum, I would consider the Senate as a place where substantial freedom of speech was in fact exercised.

The comitia were a completely different story. They were not deliberative bodies as the Athenian Assembly was ${ }^{32}$; citizens did not have the right to speak at them, but only to vote ${ }^{33}$, and thus discussion before the voting was not allowed ${ }^{34}$. How could it be so? How can it be understood that the Roman people had the greater right to vote but lacked the lesser right to speak freely at these meetings?

${ }^{21}$ Cicero, Orations (against Lucius Calpurnius Piso). See also: Robinson, Laura, cit. (n. 12), pp. 39-40.

${ }^{22}$ Robinson, Laura, cit. (n. 12), p. 40.

${ }^{23}$ As mentioned above, several authors affirm that political rights and liberties in Rome were primarily conferred to the elite. See Millar, Fergus, cit. (n. 10).

${ }^{24}$ RaAflaub, Kurt A., cit (n. 3), p. 55.

${ }^{25}$ Mommsen, Theodoro, Compendio del Derecho Público Romano (Buenos Aires, 1942), p. 428 .

${ }^{26}$ LintotT, Andrew, The Constitution of the Roman Republic (Oxford, 1999), p. 76.

${ }^{27}$ Mommsen, Theodoro, cit. (n. 25), p. 428.

${ }^{28}$ Mommsen, Theodoro, cit. (n. 25), pp. 80-81.

${ }^{29}$ Sallust's account of the debates regarding the punishment of those involved in the conspiracy of Catiline is very illustrative on this matter. See GaIUS SAlLustius CRISPUS, The Jugurthine War and The Conspiracy of Catiline (London, eng. tra., 1963) pp. 215-227.

${ }^{30}$ Mommsen, Theodoro, cit. (n. 25), p. 430.

${ }^{31}$ Caesar ordered daily journals of the proceedings to be published. RoBInson, Laura, cit. (n. 12), p. 38.

${ }^{32}$ Millar, Fergus, cit. (n. 10), p. 146.

${ }^{33}$ Finley, Moses, Politics in the Ancient World (Cambridge, 1983), p. 86. See also: WiltsHIRE, Susan, cit. (n. 8), p. 116, and LinTotT, Andrew, cit. (n. 26), p. 41.

${ }^{34}$ RaAflaub, Kurt A., cit (n. 3), p. 54. 
The answer to these questions seems to be provided by Cicero: voting did not mean share in the governing power or in the deliberative function ${ }^{35}$. In other words, the comitia were not really sovereign; their only function was to decide among very narrow choices offered to them. No discussion was needed because it was not the purpose of the meeting to come up with propositions or to handle political problems by itself.

Therefore, even if exceptionally a chance to speak was given to "privatis magistratibusve audiendis" 36 , there is clearly not much exercise of freedom of speech at the comitia. Partial exception to this were the elections taking place at the comitia, which did provoked a substantial amount of freedom of expression before they took place. In fact, political propaganda was common in Rome ${ }^{37}$ by way of speeches, cryptic drama, poems, lampoons ${ }^{38}$, and also by way of written commendations painted on roads and walls of the candidates' clients ${ }^{39}$.

Courts also seem to have been a place particularly tolerant of free speech. In fact, legal counseling could be aggressive in the use of personal disqualification and defamation during legal procedures ${ }^{40}$. Lawsuits were constantly used as a powerful weapon against political enemies, specially tailored to destroy their reputation and credibility ${ }^{41}$.

The case of the army is a very extraordinary one. In contrast to contemporary ideas about military discipline, Roman soldiers seem to have discussed frequently about politics and public affairs. As Chrissanthos explains: "Contrary to the picture painted by Polybius and many modern historians, the Roman Republican soldier was not always unquestioningly obedient to his commander. Since he was first and foremost a Roman citizen vested with certain important rights, the Roman soldier inherited a long tradition of independent thought and action" ${ }^{\prime 2}$.

The key issue here is that soldiers were also citizens, and therefore they were entitled to libertas, even when in campaign. This idea is reinforced by the fact that military commanders were also the political leaders of the day, which in turn should have shown a military background to be elected ${ }^{43}$. Thus, the situation in the army, as a whole, closely resembled the political situation in the city. Additionally, the popular thought about libertas is not only connected with the end of the monarchy, but also with the old quarrels between patricians and

${ }^{35}$ Cicero, De Re Publica, 1, 31.

${ }^{36}$ Cicero, De Legibus, 3, 43.: "to private citizens and magistrates".

${ }^{37}$ See Franklin, Jr., James L., Pompeis Diffcile Est Studies in the Political Life of Imperial Pompeii (Ann Harbor, 2001).

${ }^{38}$ Robinson, Laura, cit. (n. 12), p. 29.

${ }^{39}$ Stavely, E.S., Greek and Roman Voting and Elections (London, 1972), p. 194.

${ }^{40}$ BAUMAN, Richard, cit. (n. 13), p. 102, states that: "Attacks on the character were a standard manoeuvre in both political debate and trial proceedings".

${ }^{41}$ For an extended account of these practices see: RoBInSON, Laura, cit. (n. 12), p. 29.

${ }^{42}$ Chrissanthos, Stefan, cit. (n. 6), p. 342.

${ }^{43}$ Polybius, Histories, 6, 19, 4, says: "politikên de labein archên ouk exestin oudeni proteron, ean mê deka strateias eniausious êi tetelekôs" ("no one can hold an office in the state until he has completed ten years of military service"). 
plebeians, which resulted in the extension of rights and privileges to the latter ${ }^{44}$. During such a process, the army played a crucial role, as it is patent in the secession episode described by Livy ${ }^{45}$. In fact, the military was an active player in the assertion of the citizens' rights and liberties, and consequently, it is not absurd to think that a special political awareness about such rights and freedoms did exist in the army.

How could all of the above be compatible with the minimum discipline required for any army to be effective? Three factors should be considered. Firstly, soldiers swore a sacramentum when incorporated to the army, which consisted in a series of disciplinary obligations including the obedience to the commander. Notoriously, this oath did not limit the right to freedom of speech of the soldiers ${ }^{46}$. Secondly, some commanders seem to have enforced a much stronger discipline in the camps than others ${ }^{47}$. Finally, insofar as soldiers gradually became less and less 'purely Roman', i.e. not extracted from the city itself, their political awareness might have waned to certain extend ${ }^{48}$.

In any case, it is undeniable that the exercise of freedom of speech among soldiers could be very influential over commanders and courses of action. Several examples can be found of suggestions, open rebellions, threats to commanders to change their battle decisions, etc. Tacitus' descriptions of Germanicus' campaigns during the reign of Tiberius, even if carried out after the Republic, are most illustrative on this issue.

I turn now to the analysis of the main non-institutional scenarios where freedom of speech flourished during the Republic. The importance of them should not be undervalued in a "Mediterranean society in which people congregated out of doors, on market-days, on numerous festive occasions [...]" 49

The most obvious place to start with is the Forum, which was exactly that: a big forum for all the citizens of Rome. It was open, wide and 'popular'50. It was also the main stage of the influential Roman oratory tradition, which was refined to the point of art during the republican centuries. Even though collective and impulsive decisions could in fact be adopted here, some of them resulting in demonstrations and riots, the main functions of the Forum were the political education of the people, providing information on public affairs, and oratory contest. All of the above consolidated the Forum as a privileged place for the exercise of freedom of speech, despite its massive character and the chilling effect produced by the fear of the mob.

Roman private associations were also relevant for the exercise of freedom of speech. Generally speaking, informal groups seem to have been the rule, given

\footnotetext{
${ }^{44}$ Chrissanthos, Stefan, cit. (n. 6), p. 346.

${ }^{45}$ Titus Livius, The Early History of Rome (1960, reprint London, 2002), p. 146.

${ }^{46}$ Chrissanthos, Stefan, cit. (n. 6), p. 354.

${ }^{47}$ See the case of Aemilius Paulus during the Third Macedonian War in Chrissanthos, Stefan, cit. (n. 6), p. 341.

${ }^{48}$ Chrissanthos, Stefan, cit. (n. 6), 348-351.

${ }^{49}$ Finley, Moses, cit. (n. 33), p. 82.

${ }^{50}$ Millar, Fergus, cit. (n. 10), p. 149.
} 
the traditional patrician attitude against any kind of organized 'faction' that could threat their control over the plebs ${ }^{51}$. Political parties did not exist at the time, and every organized group, even burial guilds, were regarded as suspicious. During the tumultuous first century AD., Cesar went as far as to ban "all private associations as potentially subversive" 52 . Later permissibility seems to be always related with previous authorization.

On the other hand, informal groups thrived, providing "opportunities for news and gossip, for discussion and debate, for the continuing political education" ${ }^{53}$, and therefore encouraging a generous use of freedom of speech.

Lastly, I should talk about some kinds of arts in Rome, which were also used as a vehicle for freedom of speech. The first one is the satire, which "was one of the favorite modes of expression among Romans. It often took the form of incisive personal criticism" ${ }^{\text {4 }}$. Satire could be very sharp indeed, even to the most important Romans of the time, and so it was always at the borderline of what libertas allowed ${ }^{55}$. A second relevant form of art was the theatre, where the only limit, at least from the second century $\mathrm{AD}^{56}$, was the omission of the name of the 'victim' 5758 . The governmental funding of these shows might have had something to do with this restriction. A third kind of art employed for political speech was poetry, which did not bother too much in order to conceal its most snapping criticism $^{59}$. Historians during the Republic seem also to have enjoyed a broad freedom to conjecture, as Tacitus nostalgically remembered ${ }^{60}$.

Thus, several types of art were used on regular basis to convey political speech. Even though criticism was open, sharp and even merciless, censorship was not really enforced by the state ${ }^{61}$, nor were libel actions filled in courts.

Summing up, republican times displayed a rich vibrant exercise of freedom of speech through the most varied means. It was not only a feature of the Roman institutional life, but also of its society as a whole.

${ }^{51}$ Wiltshire, Susan, cit. (n. 8), p. 128.

${ }^{52}$ Wiltshire, Susan, cit. (n. 8), p. 128.

${ }^{53}$ Finley, Moses, cit. (n. 33), p. 82.

${ }^{54}$ Robinson, Laura, cit. (n. 12), XI.

${ }^{55}$ For an extend treatment of the issue, see Morton Braund, Susanna, cit. (n. 14), p. 409, where the author distinguishes licentia from libertas: "where libertas is used to denote an exercise of freedom of which the speaker approves, while licentia denotes an exercise of freedom of which the speaker does not approve".

${ }^{56}$ Possible time of the new law on iniuria. See Robinson, Laura, cit. (n. 12), p. 7.

${ }^{57}$ Bauman, Richard, cit. (n. 13), p. 103.

${ }^{58}$ Robinson, Laura, cit. (n. 12), p. 6, describes a civil suit of a plaintiff "against a mime for addressing him by name on the state".

${ }^{59}$ Robinson, Laura, cit. (n. 12), pp. 50-51.

${ }^{60}$ As TACITUS, Annals, 4, 33, says: "tum quod antiquis scriptoribus rarus obtrectator, neque refert cuiusquam Punicas Romanasne acies laetius extuleris ("then, again, an ancient historian has but fee disparagers, and no one cares whether you praise more heartily the armies of Carthage or Rome”).

${ }^{61}$ Chrissanthos, Stefan, cit. (n. 6), p. 344; and Robinson, Laura, cit. (n. 12), p. 51. 


\section{The Empire.}

The change on the political regime deeply affected freedom of speech. As Robinson states, "The shifting of the governmental control from democratic machinery to one-man power made the ultimate suppression of open political criticism inevitable" 62 . However, this transformation was neither a one-day phenomenon, nor was it clearly perceived as such since the beginning of it.

It is important to consider that the permanent violence of the late Republic surely was not the best scenario for rights and liberties. Those require the rule of law and order to flourish; chaos destroys them. In this context, Augustus affirmation in Res Gestae that "rem publicam a dominatione factionis oppresam in libertatem vindicavi ${ }^{163}$ makes some sense ${ }^{64}$. Moreover, it may explain why many regard the empowerment of Augustus as the reestablishment of the old Republic, understanding for it, more than a specific structure of government, the rule of law and the rights and liberties of the people ${ }^{65}$. Then, it is not such a surprise that Wirszubski affirms that "Under Augustus the essential rights and liberties of Roman citizens remained untouched"66.

Notwithstanding the above, in the long run the empire proved to be a bitter enemy of the old libertarian ways. Politically, the comitia lost in fact their monopoly over elections and legislation, and were even suppressed ${ }^{67}$. The Senate, formally entrusted by Augustus with the supreme power ${ }^{68}$, became a puppet of the emperor ${ }^{69}$. Contio and public meetings at the Forum and everywhere else progressively lost their most pure political component. The emperor and its court concentrated all the power, and therefore politics were discussed there. The apparatus of the Republic became mainly decorative ${ }^{70}$, and citizenship became less and less important as a political fact, even if it retained important legal consequences.

Unlimited freedom of speech became superfluous to the political system and dangerous to safe rule ${ }^{71}$. Progressive restrictions were quickly established by law; defamation was criminalized, writings were burned, and authors were condemned for what they wrote.

\footnotetext{
${ }^{62}$ Robinson, Laura, cit. (n. 12), p. 80.
}

${ }^{63}$ Gaius Julius Caesar Augustus, Res Gestae Divi Augusti, 1: "I successfully championed the liberty of the republic when it was oppressed by the tyranny of a faction".

${ }^{64}$ EARL, Donald, cit. (n. 2) p. 63: "The People wanted security and order, not the chaos of the late Republic".

${ }^{65}$ EarL, Donald, cit. (n. 2), p. 64.

${ }^{66}$ WirszubsKI, Chaim, Libertas as a Political Idea at Rome during the Late Republic and Early Principate (Cambridge, 1950), p. 122.

${ }^{67}$ In the case of the elections, they were suspended, then restored and intervened. See WirSZUBSKI, Chaim, cit. (n. 66), p. 19.

${ }^{68}$ Earl, Donald, cit. (n. 2), p. 63.

${ }^{69}$ There are some hints that some senators did try to retain their freedom of speech, at least as a privilege or as a duty. See Wiltshire, Susan, cit. (n. 8), p. 117 and Epictetus, cit. (n. 11), p. 19.

\footnotetext{
${ }^{70}$ EARL, Donald, cit. (n. 2), p. 63.

${ }^{71}$ Robinson, Laura, cit. (n. 12), p. 55.
} 
Again, the process of erosion of freedom of speech was not a lineal one. The particular character of each emperor, as well as his stance towards criticism, proved to be crucial. Thus, Augustus attitude towards freedom of speech was complex. On one hand, he tried hard to maintain the illusion that the Republic was reestablished, and so he did not persecute anybody for criticism against himself. That was the custom of the magistrates of old, including Caesar. On the other hand, it was clear since he was a triumvir that he was not very tolerant regarding senatorial $\mathrm{critic}^{72}$, and during his time fundamental legal changes limiting freedom of speech were adopted (e.g. extension of the lex Maiestatis; anonymous pamphleteering was made a criminal offence $)^{73}$.

Tiberius continued to enforce the new laws against freedom of $\operatorname{speech}^{74}$ : works were burned and writers exiled ${ }^{75}$. Some authors praise Tiberius 'clemency' in several cases ${ }^{76}$, which clearly confirms that freedom of speech had to some extended ceased to be a real 'right': it depended on the will of the emperor ${ }^{77}$.

Later emperors tended to tight their control over political speech, with some relatively freer periods in between (e.g. Vespasian's reign). This process continued until Domitian, who seems to have eradicated once for all the lasting reminiscences of the old republican freedom of speech. In fact, he applied a policy of complete repression through death sentences, exile and writing burning ${ }^{78}$. After him, prorepublican ideas (focus of the imperial persecution) were abandoned by their last organized defenders, i.e. the Stoics ${ }^{79}$.

Did any freedom of speech survive during the empire? Yes, some did. Firstly, satirist, historians and poets did not disappear ${ }^{80}$. The trick was to be smart enough to say things without being obvious about it. In words of Quintillan: "quamlibet enim apertum, quod modo et aliter intelligi posit, in illos tyrannos bene dixeris, quia periculum tantum, non etiam offensa vitatur" ${ }^{11}$.

${ }^{72}$ Robinson, Laura, cit. (n. 12), p. 56.

${ }^{73}$ BaUman, Richard, cit. (n. 13), p. 104.

${ }^{74}$ Bauman, Richard, cit. (n. 13), p. 101. Cf. TaCitus, Annals, 1, 72.

${ }^{75}$ For a more comprehensive account of convictions during this time, see: $\mathrm{McHuGH}$, Mary, Historiography and Freedom of Speech: The Case of Cremutius Cordus, in SLUITER, Ineke - Rosen, Ralph M. (eds.), Free Speech in Classical Antiquity (Leiden, 2004), pp. 406-407. See also: BAUMAN, Richard, cit. (n. 13), p. 101.

${ }^{76}$ Robinson, Laura, cit. (n. 12), p. 81.

${ }^{77}$ Cf. TACitus, Annals, 1, 73; 1, 74.

${ }^{78} \mathrm{McHugh}, \mathrm{Mary}$, cit. (n. 75), p. 406.

${ }^{79} \mathrm{McHugh}, \mathrm{Mary}$, cit. (n. 75), p. 406.

${ }^{80}$ See also Morton Braund, Susanna, cit. (n. 14), p. 426: "Satire knows that it can incur censorship and censure and that it can sidestep censorship and censure, if it is clever enough". McHugh, Mary, cit. (n. 75), p. 392, adds: "the historian can still communicate the lessons of history under tyranny, that critical and meaningful speech, is possible even when the modes of expression are severely restricted".

${ }^{81}$ QUINTILIAN, Institutes of Oratory 9,2,67: "For we may speak against tyrants in question as openly as we please without loss of effect, provided always that what we say is open to a different interpretation, since it is only danger to ourselves an not offence to them, that we have to avoid." 
Some authors as Tacitus (criticizing Tiberius and even Augustus) ${ }^{82}$ and Dio Cassius (criticizing the monarchical system inaugurated by Augustus and highlighting the value of freedom of speech $)^{83}$ seem to have been successful in avoiding punishment for their political speech. However, this was a dangerous game and not all who tried it survived. The most recorded failure was that of Cremutious Cordus, whose praise of Brutus and Cassius were taken as an overt exultation of the Republic and a rather clear reproach to Augustus and Tiberius. His works were burnt and he died by self-starvation ${ }^{84}$.

Secondly, some public opinion remained, at least during the first emperors. For example, the dangerous extension of the Lex Maiestatis ${ }^{85}$ provoked a strong opposition. As explained in section VI below, this law was transformed, allowing emperors to punish anything that could possibly diminish their dignity in almost any conceivable way. Obviously, abuses were likely to take place. Remarkably, public pressure led most emperors to suspend the law (even if they restored it later, or found analogous arbitrary means to pursue similar objectives). Finally, Severus Alexander ruled out the use of this law ${ }^{86}$.

Thirdly, some writers, historians and poets obtained the emperor' favour, thus having much more leeway in their work. This would be the case of Horace ${ }^{87}$, who was protected by Augustus himself.

Fourthly, non-political critic was still possible to a significant extend. Thus, satire continued to be a very popular and rather itching art in $\mathrm{Rome}^{88}$, and private actions of libel were not so uncommon.

Overall, it can be said that the empire progressively destroyed freedom of speech in the Roman world. Even if some of it survived, it ceased to be considered as a right and it stopped to be necessary for the functioning of the political system. Thus, the new regime mortally wounded both dimension of freedom of speech.

\section{WHAT WAS THE ROMAN LAW ON FREEDOM OF SPEECH?}

There was never in Rome an express legal or constitutional recognition of the right of freedom of speech. In fact, it was the result of a continuous and expanding practice linked with the instauration of the Respublica, which guaranteed the broad concept of libertas. As already mentioned, libertas seemed to have encompassed a series of rights and freedoms, including freedom of speech.

Legal limitations on this right seem to have developed together with the right itself. The more it was used, the more it was abused, and the more restrictions

\footnotetext{
${ }^{82}$ Bauman, Richard, cit. (n. 13), particularly pp. 31-89.

${ }^{83}$ Lucius Cassius Dio Cocceianus, Roman History, (1914, eng. trad., Cambridge), IV, p. 87 ff. and p. 159.

${ }^{84}$ For a complete account of the case, see McHuGH, Mary, cit. (n. 75), also mentioned in Robinson, Laura, cit. (n. 12); and Wiltshire, Susan, cit. (n. 8), p. 118.

${ }^{85}$ BAUMAN, Richard, cit. (n. 13), p. 107.

${ }^{86}$ BAUMAN, Richard, cit. (n. 13), p. 108.

${ }^{87}$ Robinson, Laura, cit. (n. 12), p. 64.

${ }^{88}$ Morton Braund, Susanna, cit. (n. 14), p. 417.
} 
were tried on it. On the whole, legal curtails failed to be successful during the Republic. Additionally, the State lacked effective repressive mechanisms of freedom of expression (i.e., secret police or the like) ${ }^{89}$.

The XII Tables were probably the first Roman written legislation that explicitly regulated freedom of speech, establishing an action against libel or defamatory writing. I said 'probably' because there is some dispute about the correct meaning of the old text, which could also be understood as only prohibiting magical practices. In any case, its application seems to have been rather uncommon ${ }^{90}$.

Later on, maybe influenced by the Nevious case (application of the XII Tables to slander in plays $)^{91}$, a new law on injuria was most likely enacted during the second century BC, possibly only applicable against attacks by name shouted from the stage ${ }^{92}$.

On the Gracci period (last third of the second century BC) the Lex Maiestatis was enacted, which was understood as punishing "si quis proditione exercitum aut plebem seditionibus, denique male gesta re publica maiestatem populi Romani minuisset" ${ }^{33}$. This law will became crucial, as explained below ${ }^{94}$.

In the year $91 \mathrm{BC}$, the lex Remmia criminalized malicious lawsuits as calumnia (a common practice in Rome for the damaging of political enemies). Its effectiveness in terms of discouragement of legal actions and convictions seems to have been low ${ }^{95}$.

Then, a general law against libel was enacted during Sulla's dictatorship, which proved fairly difficult to use in practice ${ }^{96}$. Additionally, praetorian edicts granting actions of injuria for public slander (called convicium) were rare ${ }^{97}$.

Once the empire was established, legislation regulating freedom of speech became substantially stricter. The crucial change was provoked by Augustus, who expanded the Lex Maiestatis to "slanderous writing"98 against "great people"99. Thus, he changed the original nature of that Lex, making it a strong version of the old libel laws. Defamation was now a crime and not just a civil wrong emendable by compensation $^{100}$. Conviction resulted in the burning of the author's writings ${ }^{101}$.

From this point forward, the expansion of the Lex Maiestatis seems to have

${ }^{89}$ Chrissanthos, Stefan, cit. (n. 6), p. 344.

${ }^{90}$ Robinson only found three cases. See Robinson, Laura, cit. (n. 12), p. 27.

${ }^{91}$ Robinson, Laura, cit. (n. 12).

${ }^{92}$ Robinson, Laura, cit. (n. 12), p. 7.

${ }^{93}$ TACITUS, Annals 1, 72.: "betrayal of an army, seditious incitement of the populace, any act, in short, of official maladministration diminishing the majesty of the Roman nation".

${ }^{94}$ See also McHugh, Mary, cit. (n. 75), p. 393.

${ }^{95}$ Robinson, Laura, cit. (n. 12), p. 11-12.

${ }^{96}$ Robinson, Laura, cit. (n. 12), p. 51.

${ }^{97}$ Chrissanthos, Stefan, cit. (n. 6), p. 346.

${ }^{98}$ McHugh, Mary, cit. (n. 75), p. 393.

${ }^{99}$ Robinson, Laura, cit. (n. 12), p. 58.

${ }^{100}$ Bauman, Richard, cit. (n. 13), p. 102: "In the Republic defamation had been a delict, a civil wrong generating a claim for pecuniary damages; but there had been no criminal sanction".

${ }^{101}$ McHugh, Mary, cit. (n. 75), p. 393. 
been a main source of abuse. In the words of Bauman: "The maiestas law rapidly attained such a degree of flexibility that it protected the persona of the deified predecessor, as well as that of the incumbent ruler, against any diminution of his dignity, status or security" 102 .

Unsurprisingly, this law became a tool of arbitrariness, particularly in the hands of eccentric emperors. For example, it was invoked against "a member of the audience who failed to listen attentively to Nero's 'heavenly voice' and [against] a woman who undressed in front of a statue of Domitian"103.

As mentioned before, public opinion strongly pressed against the application of the ever-expanding lex Maiestatis, obtaining its suspension with regularity until its final disappearance under Severus Alexander (III century AD). However, the end of the lex Maiestatis did not mean that defamation ceased to be illegal. In fact, several decrees from $319 \mathrm{AD}$ to $406 \mathrm{AD}$ "provided for the destruction of defamatory writings and the punishments of the authors" 104 .

As a whole, the legal dispositions mentioned above increasingly encroached on freedom of speech. They were not dead letter; several convictions were imposed on their account during the empire ${ }^{105}$. Moreover, the political context in which these laws were applied was clearly more willing to enforce them than the one during the Republic.

\section{CONCLUSIONS}

Freedom of speech was definitely present in the Roman world, at least during the Republic. The variety of its manifestations, as well as the persistent strength of them, are prove enough of the crucial importance and extended exercise of freedom of speech in Rome.

In spite of a different theoretical framework, similarities with modern times are striking. Thus, Romans used freedom of speech as a tool to criticize 'the government'; to tease their fellow citizens; to have fruitful deliberations; to attack political enemies; to have a real participation in the Respublica; to articulate and spread political ideas; etc. In short, they used it to provoke change and to exercise freedom. Additionally, from a legal point of view, Romans seem to have been even freer to talk aloud than any modern nation. In fact, defamation laws were scarce and rarely applied.

The empire was a disaster for freedom of speech. Change was combated and freedom restricted through several means, including the law. The key concept of citizenship, which combined the social and individual dimensions of freedom of speech, lost all real political meaning. Freedom of speech became redundant. It

\footnotetext{
${ }^{102}$ BaUman, Richard, cit. (n. 13), p. 107.

${ }^{103}$ BaUman, Richard, cit. (n. 13), p. 107.

${ }^{104}$ BAUMAN, Richard, cit. (n. 13), p. 108

${ }^{105}$ McHugh, Mary, cit. (n. 75), pp. 406-407. Other authors also provide some examples. See, inter alia: Robinson, Laura, cit. (n. 12); BAUMAn, Richard, cit. (n. 13); and TACitus,
} Annals, etc. 
did not fade away completely, but it lost its most important functions as well as it status as a 'right'. Fear and submission followed with few exceptions.

[Recibido el 1 de junio y aprobado el 4 de julio de 2009]. 
